\title{
Impact of Security Issues on Pakistan-India Relations: Remedies and Political
}

\author{
Advantages \\ * Muhammad Tasleem Ashraf, PhD Scholar \\ ** Dr. Ali Shan Shah, Assistant Professor \\ **** Dr. Zil-e-Huma Rafique, Assistant Professor
}

\begin{abstract}
The history of Pak-India relations has presented sound evidences that both states harvested distrust and uncertain conditions with each other after the end of British colonial rule in the sub-continent. Since the partition, both states have contentious issues which added more fuel to both sides' relations. Kashmir issue is a dominant factor that has created more unrest as both states strained into three fullscale wars in this connection. Mutual disputes have also created issues of security and cross-border terrorism which put obstacles during the peace process between India and Pakistan. Concerns about security and cross-border terrorism are counted as a serious constant threat to peace in the South Asian region as both countries have the capability of nuclear war. Pakistan is blamed for Cross border terrorism which is a big matter of concern by the Indian side. India claimed that through cross-border terrorism, Kashmir and the Indian Parliament were attacked with the backing of Pakistan. Mumbai attacks were also engineered in the same pattern to create unrest and security issues in India. On the other hand, Pakistan denied Indian allegations and has bourse concerns about India's involvement in Baluchistan and different suicide attacks in Pakistan. The study tries to explore the involvement of non-state actors in cross-border terrorism and its aftershock in both sides' relations. The study also explores the impacts of cross-border activities and the peace process between Pakistan and India. It examines the different measures taken by Pakistan to stop terrorism in the region for developing sustainable ties with India.
\end{abstract}

Keywords: Cross border terrorism, security issues, Peace process, Mutual disputes, Regional Introduction Instability

Dietrich Fischer has narrated two aspects of security, first absence of objective threats which are associated with state survival, and second absence of subjective fear of being insecure and living in uncertain conditions. Security is the condition in which States are enjoying the possibilities of development and progress without any threat of military attacks. States ensure the security of their individuals and communities. The basic essential needs of any state citizens are closely associated both with external and internal security such as survival and safety of life, pure diet, housing, education, and freedom of utilizing the capacities for individual progress and freedom. Security is the condition that guarantees a safe liveable environment in which the social, economic, and political rights of the people are protected without external and internal threats. Security is also the condition of mind in which there is no psychological fear or anxiety of being unsafe from dangers (Budania, 2001, pp. 17-18).

The term "Security" can be defined as a state free from the threat of war and people of the state are living peacefully without internal and external security threats, violent activities, or any act of terrorism. In India and Pakistan since their birth, both states have mutual issues which have pushed them into conflicts. Constant condition of distrust is always observed present between the ties of both nations. Indian dream for her hegemony and domination in the region has created obstacles and challenges for security. The birth of Pakistan was counted as a tragic and illegal event by Indian leadership (Majeed, 2013, p. 212).

* Department of Political Sciences and IR, Government College University Faisalabad

** Department of Political Sciences and IR, Government College University Faisalabad

*** Department of History and Pakistan Studies, Government College University Faisalabad 
The history of both states shows that mutual despites have created uncertainty and constant threats to peace and security which is examined as a great matter of concern because both states have the capability for nuclear attacks on each other. This nuclear capability is a constant threat to regional security but as well as to international peace. In the past India and Pakistan has the worst experience of full-scale wars in 1965 and 1971. War of Kargil in 1999 and terrorist attacks on Kashmir and Indian parliament have created unrest and deep concern over cross border terrorism according to the Indian point of view. The Indian involvement in creating unset in Karachi and Baluchistan and different terrorist attacks in Pakistan has added more fuel to security concerns according to the Pakistani perspective (Mustafa \& Ashraf, 2016, p. 65).

Regional geographical position showed that both India and Pakistan are connected with long shared border areas. Security concerns have always been present in the minds of both sides' policymakers. Security threats fetched more attention while the history of relations between both countries was examined as not normal. Pakistan, being a small country feels always dreaded and threatened as its rival state has huge military expenditures. Indian has the superior capabilities for attacking on land, air, and sea zones as compared to Pakistan which has raised the deep security for regional stability. India wants to acknowledge and establish its dominance in the south Asian region. Many rounds of talks, dialogue processes, and discussions were formulated in different periods at all levels to address the standing issues between both countries but no breakthrough was observed. Nuclear arms completion has increased the worries for the peace and security of the region. This blind arms race for enhancing more advanced nuclear technology has articulated new challenges and deep concerns for the peace and stability of South Asia. The root cause uncertainty and bad relations between both India-Pakistan because of unsolved Kashmir issue (Adnan, 2013, pp. 131-132).

\section{Purpose and Significance of the Study}

The Objectives of this research paper is to analyze the issues of security and cross-border activities of terrorism and their repercussions on the relations of both India and Pakistan. This study will also examine how the dialogs process stopped after cross-border terrorism and its consequences over the regional politics of South Asia. The objective of the study is to analyze the measures taken by Pakistan to combat issues of security and terrorism for durable peace and her efforts to fight against every kind of terrorism in the region. The study will also examine the Indian and Pakistan concerns on one another about cross-border terrorism and its effects on regional stability of South Asia as well as the impacts on international politics. The study will also examine the mutual contentious issues as driving forces for cross-border terrorism and creating barriers for normalizing relations on both sides.

The study will be significant for the students of international relations to understand the bad impacts of cross border terrorism over mutual relations of countries as well as aggravating regional instability. The study will be beneficial for understanding how mutual contentious issues create distrust among nations and create problems for developing friendly relations especially in the case of India and Pakistan. The study will also help to analyze how non-state actors played their role to stop the peace process and establishing the blame gaming and distrust between countries. The study has also suggested some suitable measures for stopping cross-border terrorism and developing mutual trust in India and Pakistan. The literature has also highlighted measures taken by Pakistan to combat terrorism in its every shape and it will be beneficial to understand how the state avoided the conflict for establishing peace in the region.

\section{Hypothesis}

H 1.Issues of security between India, Pakistan have created, concerns distrust, and a high risk for peace in the South Asian zone.

H 2.Acts of cross-border terrorism stopped the process of composite dialogs and established unrest in bilateral relations.

H 3.Mutual disputes remained unsolved due to terrorist activities and blame gaming on one another.

\section{Methodology}

For collecting the evidences both qualitative and quantitative approaches are used. Official statements of both sides' foreign offices, policy briefings, books, research articles, research reports, national newspapers, and magazines are used to collect and analyze data. The research will be descriptive.

\section{Security Concerns and Pak-India bilateral Conflicts}

In the mountain of the Himalaya region of both sides since the departure of the British from the subcontinent, Kashmir was seen under the shadow of guns as India, Pakistan have engaged the military 
forces to control the Himalaya mountain region. Under the 47 Resolution which was passed on 21 April 1948 by the UN Security Council, National Referendum was called on the future of the Kashmiri people. India continues to object while Pakistan is willing to implement a resolution passed by Security Council. The line of control (LOC) covering the 463 miles in the Himalayas sector which separates India, Pakistan is always under high-security threat. UN played its role for ceasefire in 1948 and again in the war of 1965. Both sides again went to war in 1971 as the unsolved Kashmir dispute was the main reason behind all armed clashes. Pakistan clime on Kashmir is not just because of Muslims population but farming in Pakistan is mostly irrigated with the control of the headwaters in the occupied valley of Kashmir. Indian fears that the settlement of this dispute will lead the other states of India to separate identity (Researchers, 2009, p. 140)

After independence, the security concerns and issues between Indo-Pak have been observed as the dominant factor. Both countries fought three full sale wars. Indo-Pak bilateral conflicts and outstanding issues have caused a sense of insecurity in the region. Pakistan joined the western block after independence because of security threats from India. The race of arms, endless efforts for increasing the military capabilities is a sign of distrust and insecurity. Indian attempt to make her hegemony in South Asia is not acceptable to Pakistan due to security threats from India. Kashmir, Siachen, Sir Creek, Water Dams project disputes and issues of security and terrorism has generated more complex situation in the region. Interference in internal matters of one another country is also counted many times. Both countries think internal interference is attempting to weaken their sovereignty. After getting the status of nuclear Powers, regional responsibilities of security have been increased on both Nations. It is strongly considered that Indo-Pak nuclear capacities are a threat to one another and also a matter of great concern for the other regions of the world. Terrorism and security concerns are interconnected with each other and any act of terrorism in both countries always created distrust and a sense of insecurity.

\section{Establishment of Regional Convention on Suppression of Terrorism}

Regional Convention on Suppression of Terrorism (RCST) was signed on $4^{\text {th }}$ November 1987 and came into force on 22 August 1988 after ratification of all SAARC States. Nations showed their full assurance to share expertise, intelligence, and information for extraditing terrorism and making a haven for the people of the South Asian zone (Trivedi, 2008, p. 140).

In Kathmandu 2002 a legal team of advisors was set up by SAARC States to draft on Additional Protocol of SAARC Convention on Suppression of Terrorism. Ministers Councils, senior officials, and a team of legal experts met and discussed the various aspects of the draft. In Islamabad during twelve yearly Summit Council of Minister signed the draft. It was implemented after confirmation of all SAARC countries in January 2006 (Wignaraja \& Hussian, 1989, p. 351).

\section{Rajiv and Benazir Bhutto meet in Islamabad}

Benazir Bhutto and her counterpart Rajiv Gandhi signed an accord in December 1988 during SAARC Summit not to attack against nuclear installation and ratified in 1991 and the accord enforced in January 1992. The chemical weapons bilateral pact was organized in 1992 as both States agreed not to breed and develop chemical weapons. Indian Prime Minister Narasimha Rao and Nawaz took few steps for Confidence-building measures to reduce tension from 1991-1993. During eight Summit in New Delhi May 1995 the participation of former Pakistani President Farooq Leghri agreed for SAARC vision for the second decade also indicated a step towards trust and cooperation. Gujral Doctrine, its implications on the south Asian region in 1996-97. (Jabeen, Mazhar, \& Goraya, 2010, pp. 133-134)

In 1988, Prime Minister Benazir and Rajiv made an important agreement to promote trust and peace between the people of both nations. It was an accord established between both sides to remove the misrepresentation and hated material published in the textbooks of history. Both leaders agreed to remove images, which are articulating the concept of hate, aggression, and enemy in the publications of both sides curriculum. It was a cultural agreement to develop peace in both nations by eliminating hated material (Ahmed \& Das, 1998, p. 18).

\section{Regional Security and Pakistan}

Pakistan has to face problems of self-survival from the day of her formation. State was pushed into the crisis soon after it started her journey as an independent Muslim state. Wars of 1948, 1965, and 1971 left harsh memories for the policymakers and people of Pakistan. Pakistan has to bear the aftermath of the 1971 war which caused the fall of Dhaka, East Wing of Pakistan was forcefully 
separated from her West Wing. It was an unbelievable loss for new developing state. Ninety thousand army men were arrested by the Indian forces, with tragic memories future survival of the state was at stake.

Zulfiqar Ali Bhutto was the person who articulated the thinking for Nuclear Pakistan after the devastating loss in 1971. Bhutto's beliefs for nuclear capability got more strength when India conducted a nuclear test in 1974. Nuclear weapons became a necessity for the security of Pakistan. In the case of India, it was observed that India lost the war with China in 1962. Chinese conducted the nuclear tests in 1964 at Lop Nor. After the Chinese nuclear explosive, Jawaharlal Nehru and Homi Bhabha the Indian chief scientist thought that nuclear weapons are compulsory for Indian national security. One of the factors behind this approach of Nehru for Nuclear India was war with China and Nuclear tests by the Chinese which created an imbalance in the region.

Z.A Bhutto with the same approach narrated in 1965.

"If India makes an atom bomb, then even if we have to feed on grass and leaves or even if we have to starve. We shall also produce an atom bomb as we would be left no other alternative. The answer of an atom bomb can only be atom bomb." (Khan, 2012, pp. 6-8)

\section{Atomic tests of India-Pakistan and South Asian Security}

New Delhi tested her first nuclear explosive in 1974 and after the gap of twenty-four years, five tests were conducted in the desert of Rajasthan on May 11 and May 13, 1998. The world was shocked and surprised because it was done by the BJP which came into power four weeks ago after the general election of India. May 1998 nuclear tests by both India-Pakistan threw the region into a dangerous nuclear war zone. The possibility of war seemed always looming as both countries have mutual conflicts which are fully packed with the legacy of deep-rooted rivalry (Perkovich, 2001, pp. 2-3).

Nuclear tests have opened the debate over the future security concerns of the region or the rest of the years into speculations. According to the optimistic observers, nuclear status would stabilize the security situation of South Asia. On realist grounds, it would create a balance of power and psychological pressure on the policymakers of both sides that nuclear war will ultimately bring for mutual mass destruction. The nuclear status of both sides has bound them to remain away and improve the regional security through better ties. According to the pessimistic observers, the chances of nuclear conflict have increased. They argue that the bitter history of endless rivalry has pushed both nations into an uncertain situation. A huge number of life losses and displacement of people in millions were observed as a result of historic controversies after the emergence of Pakistan and India. The deep-rooted rivalry of decades, ongoing conflict of Kashmir, and wars between both countries have jeopardized the peace of the region. Advancement into nuclear capabilities, nuclear proliferation would increase the possibility of nuclear war and south Asian regional peace will become more alarming and dangerous. Distrust and gaps between the relations Pakistan-India seems always present, any miscalculation or misunderstanding will lead to substantial mutual losses. A history of violent mutual relationships and the presence of nuclear weapons could drive both nations for mass destruction (Ganguly \& Kapur, 2012, pp. 29-30).

\section{Kargil War and Terrorist Attacks in India made Regional Peace Complex}

Kargil war in May 1999 and the troop's deployment on a large scale after the terrorist attacks on the Indian Parliament marked both countries relations into uncertain condition. Eyeball to eyeball confrontation was observed during and after Kargil as relations were noted more complex and complicated because Indian airplane IC814 was high jacked from Kathmandu to New Delhi and of terrorist attacks in Srinagar and New Delhi Parliament. New Delhi saw the involvement of Pakistani authorities behind these events. Diplomatic efforts were taken to normalize the relations such as UN Secretary-General Kofi Annan, US Secretary for State Colin Powell, and Britain Prime Minister Tony Blair paid their visit to defusing tension in Sub-contention (Mujtaba, 2005, pp. 29-30).

Kargil war and terrorist attacks on Indian Parliament led crisis in Indo-Pak relations and high threats for Regional Security. Kashmir confrontation is deeply connected with the Kargil war in summer 1999. Kargil was the first military clash between India and Pakistan that created a highsecurity threat because both States have the status of nuclear-armed powers in the Kargil war, before it was observed in the Sino-Soviet war which was occurred in 1969. Kargil remained in limited war and did not spread into large scale but raised tension and uncertainty in Pak-India relations and once again the regional security was observed on high rick (Lovay, 2009, pp. 92-93). 
The unsolved Kashmir issue between Pakistan and India is considered a great threat to the regional security of South Asia. Kashmiris' fight for liberation or self-determination raised question marks on Indian rule in Kashmir. The multiple interests in Kashmir Issue make bitterness in Indo-Pak relations. The dark side of the Kashmir issue seemed the way of armed conflict of Nuclear powers and hardly seemed towards the peaceful solution (Wirsing, 2003, p. 223).

\section{Attack on Indian Parliament and Response of Pakistan to Combat Terrorism}

India and Pakistan relations jumped into a more critical situation in 2001 and 2002 after $13^{\text {th }}$ December 2001 when the Indian Parliament was attacked by the terrorist in New Delhi. It was blamed by Indian authorities that Pakistani grounded militant organizations Laskar-e-Taiba and Jaish Mohammad have done this act of terrorism with the support of Pakistani intelligence agencies. Indian PM Vajpayee conducted a meeting with three chiefs of the Army and decided to get ready for war with Pakistan and ordered for the quick movement and more than 80,000 troops were deployed on the border area. A surgical strike was planned by Indian Air Forces to hit the terrorist in Pakistan administrated Kashmir. Islamabad also moved its forces towards border areas and Hatf one and Hatf two were installed in border regions packed with nuclear warheads (Chakma, 2015, pp. 47-48).

It is viewed that after both state's nuclear tests in May 1998, the Kargil war 1999, terrorist attacks in July 2001 on Kashmir Parliament, and attack on the Indian parliament in December 2001 reflected distrust and unrest which made the ties more complex between the two countries.

With the names tags of Lashkar-e-Tabia (LeT) and Jaish-e-Mohammad (JeM), two Pakistanibased militant groups are fighting against Indian forces in Kashmir under the control of India. Both groups have an anti-Indian approach and their aim is the freedom of the Kashmiri people. In India, both militant groups launched their targets against Indian forces in Kashmir and also hits the civilian targets. Before this, with the ranks of Mujahedeen, they were trained to fight against the forces of the Soviet Union in Afghanistan. After the end of Soviet Jihad in 1990, these groups turned their armed activities towards the freedom of Kashmir. Indian authorities thought that they were pushed towards the Kashmir cause by the Pakistani intelligence agency. Pakistani army denies the Indian allegation and marked it unjustified (Afzal, 2018).

\section{President Musharraf Banned Jaish-e-Mohammad and Lashkar-e-Toiba}

On 12 January 2002 Musharraf in his national television address to the Pakistani nation admitted that attacks on Kashmir Assembly and Indian Parliament House as an act of terrorism. At the same time, Musharraf banned the two terrorist groups Jaish-e- Mohammad and Lashkar-e-Toiba. He also asked India to resume the dialogue process for regional stability. (Prabhakar, 2003, pp. 188-189)

Soon after Musharraf's speech in January 2002 Pakistani authorities arrested near about 2000 militants and closed more than 300 offices and sub-offices of the organizations that were involved in the terrorist activities. This step was taken to develop confidence and to counter-terrorism in the region (Kumar, 2005, p. 91).

\section{Land of Pakistan would not be used for Terrorism}

Meeting of Vajpayee and Musharraf in 2004 SAARC Summit, Islamabad and Delhi agreed to recommence dialogues. Musharraf gave the commission for not allowing terrorists to use Pakistani land against India. During the twelve annual Summit of SAARC, a side-line meeting was observed on $6^{\text {th }}$ January, 2004 between Prime Minister Vajpayee and President Musharraf in Islamabad. After the sitting, India and Pakistan agreed to address the bilateral issues through talks including the Kashmir issue. States agreed to restart the Composite Dialogues Process in February. Musharraf the President of Pakistan showed his commitment that the land of Pakistan would not be allowed to use for terrorism against India. Islamabad Summit proved a milestone for trust-building on both sides (Dutt \& Bansal, 2013, p. 78).

\section{Indian Involvement in destabilizing Baluchistan}

Pakistan raised her concerns about the involvement of India in her Balochistan province. Robert G.W narrated with the reference to the report issued by the Jamestown foundation about the violence created by Baloch separatist groups to destabilizing Balochistan. According to the report issued in January 2006 more than 843 attacks and incidents of violence were examined. Fifty-four attacks were made on the security officials, Gas pipelines were attacked 31 times to stop the supply of gas to other areas of Pakistan, 291 mine blasts, and 417 rocket attacked reported. In the Kohlu district of Balochistan, 110 rocket attacks and 45 bomb blasts were reported by the separatist elements. It was the effort to destabilize Pakistan with the involvement of a foreign hand. In May 2006 same 
foundation Jamestown reported again that the main pipeline and infrastructure were attacked to stop the supply of gas to the industrial areas of Karachi and Punjab cities. (Wirsing, 2012, pp. 7-8)

Pakistan has deep concerns about the interference of Indian authorities to destabilize its Balochistan province. It was told by President Musharraf to US official Richard Boucher who visited Pakistan in January 2007. Musharraf told US officials that India was interfering in Baluchistan by supporting the planning of attacks on security forces by Akbar Bugti's grandson Brahamdagh Bugti. Islamabad expressed her concerns to the US Official that India is supporting the operations planned by the grandson of Akbar Bugti who is living in Afghanistan. Boucher assured Pakistan that the land of Afghanistan would not be used in the future. Boucher visited Kabul three days after his visit to Pakistan and talked with the Afghan administration about India and Afghanistan's support on the issue of Brahamdagh Bugti. Indian support was also examined when Baloch groups called off a ceasefire in January 2009 which was declared by Baloch separatists in September 2008 with Pakistan security forces. Interior minister of Pakistan blamed openly India for supporting BLA. An effort was observed by both leaders to resume the dialogue process between both countries. In Sharm-el-Sheikh, Indian Prime Minister Manmohan Singh met Yousaf Raza Gilani in July 2009. Singh talked about the 26/11 attacks and reminded Gilani that Ajmal Kasab was a Pakistani national who was involved in the Bombay attacks. Gilani told Singh that Pakistan had three Ajmal Kasab to show India who are involved in Bolachistan attacks with Indian support. Indian Prime minister agreed to conduct talks with Islamabad on Afghanistan-based Indian consulate interference in Balochistan (Paliwal, 2017, pp. 241-242).

\section{Mumbai Attacks a Security Dilemma}

Terrorists launched a bombing attack in Mumbai on 26, November 2008. Three days Mumbai attack shouting took the lives of 164 people and more than 300 people were wounded. Indian authorities blamed Pakistan that terrorist has the deep linkages with Pakistan intelligence agencies and terrorist received the training from Pakistani land. The Pakistan-based banned organization Lashkar-e-Toiba was involved in these attacks (Gupta \& Shukla, 2009). In the Mumbai attacks in 2008 the process of talks again postponed but it was also examined that PM Singh and PM Galini in 2010 decided to resume the dialogue process. Galini and Manmohan amended the relations of India, Pakistan. High profile officials from the Indian side Manmohan Singh, S.M. Krishna. Nirupama Rao, Arvind Metha, and Anand Sharma, and high officials from the Pakistani side Yusuf Raza Galini, Hina Rabbani Khar, Makhdoom Amin Fahim, and Robina Akhter played the key role to restart political dialogue between both States. All these measures were created to bring peace and security and to promote trade in the South Asian zone especially Between Pakistan, India (Pernes \& Moller, 2014, pp. 227-228).

\section{Kulbhushan Yadhav Case disrupted the Pak-India ties}

An Indian spy, Kulbhushan Yadhav arrested by Pakistani security agencies on March 3, 2016. Yadhav was arrested in Mashkel, the area of Balochistan. The Indian naval officer was involved in anti-state espionage, terrorism, and sabotage activities according to the officials of Pakistan. The arrest of the Indian naval commander added more fuel to the ties of Pakistan and India which were already on the boiling point after the attacks on Indian airbase Pathan Kot (Pratap, 2018, p. 299).

Yadhav was involved in anti-Pakistan terrorist activities. According to Pakistan officials, he was spying for the Indian Intelligence agency, Research and Analysis Wing (RAW). During the investigation naval officer admitted that he was involved in many activities of terrorism in the different areas of Balochistan and Karachi. Yadhav also confessed that he is working for the Indian Intelligence agency RAW as a spy. Indian refused to accept the confessional statement given by Yadhav and marked it as fabricated propaganda by the Pakistani side to achieve the political advantage. After the trial, Kulbhushan Yadhav was given the sentence of death by the Pakistani military court under the provisions of the secret army act. Indian approached the international court of justice putting the allegation on Pakistan that India was not given the consular assessment under the provisions of the Vienna convention. Yadhav case derailed the diplomatic ties between both counties. Indian officials through their statements threat to Pakistan with dire consequences and also refused to accept the status of Yadhav as serving commander in the Indian navy. The relations between both countries were not smooth before the arrest of Yadhav, the dialogue process was postponed after the attacks on the Indian Airbase, Pathankot in January, 2016. The case of Yadhav made the relations more critical. Yadhav's arrest for Pakistan is of utmost importance because the confessional statement 
of Yadhav is evidence to show the international world that Pakistan is a victim of terrorism by India (Amjad, Usman, \& Ajmad, 2017).

\section{Uri, Pathankot, and Pulwama Attacks in India made ties complex}

Pulwama terrorist attack has pushed the ties of Pakistan and India into turmoil. A twenty-year-old suicide attacker, Adil Ahmed Dar a resident of Pulwama hit the Indian convey with an explosive loaded van. According to the statement, issued by the (CRRF) IG operational, they had not received any alert from the intelligence bureau about the possibility of the suicide attack. The governor of Jammu and Kashmir Satya Pal Malik expressed that it was the failure of intelligence agencies. The related institutions of security could not detect the vehicle, its movement, and even explosives loaded for attack.

Warfare playing of Pakistan and India is not limited to Indian-held Kashmir but it can be observed in Afghanistan and inside Pakistan. Both states are have been viewed as engage in Afghanistan. Pulwama attack can be examined as a response of proxies from the Indian side to destabilize Pakistan. In July 2018, Siraj Raisani a pro-Pakistan Balochi leader was killed by a suicide attacker. More than 147 people were also lost their lives in this suicide attack. In November 2018, Bloch rebels attacked the Chinese Consulate in Karachi. In the district Loralai of Bolachistan, several suicide attacks were observed on the police and military garrisons. Pakistan viewed it as a part of a proxy war by India to destabilize its security (Feyyaz, 2019, p. 71).

JeM took responsibility for the Pulwama attack. Before this attack, JeM has been seen active in India since 2001. JeM came into the limelight after the attack on the Indian parliament. Indian also blamed JeM for piloting attacks in Pathankot and Uri. Pakistan has already banned this organization after the attack of the Indian Parliament. Indian air force attacked Balakot after twelve days on February 26, 2019, after the suicide attack of Pulwama. Indian claimed that it had dropped bombs in Balakot in Pakistan occupied Kashmir to destroy the training centers of terrorists. Pakistan retailed at once and considered it an attack on her sovereignty. On February 27, 2019, aerial combat was observed between both countries. It happened after 48 years before this air combat was seen in the war of 1971.AbhinandnanVarthaman, the Indian air force wing commander was arrested by the Pakistan air force after shot down an Indian MIG 21 air fighter. Abhinandnan was captured and Pakistan handed over the pilot to India to create a goodwill gesture and reduce the tension (Thorpe \& Thorpe, 2020).

February 2019 attack in Pulwama on Indian security forces created an ugly stability between the nuclear powers of South Asia. Devin T. Hagerty narrated that after the war of 1971, Balakot was attacked by Indian air crafts in Pakistan territory. Before this Uri attack and Indian claim for surgical strike and Pakistan refusal has its consequences on the ties of both countries. It was blamed by India that in September 2016, the Indian army was attacked by the infiltrators who crossed the Line of Control. In the Uri attacks 19 soldiers were killed. Prime Minister Modi ordered Indian forces for surgical strike in response to Uri attacks on the terrorists training pads inside Pakistan LOC (Haqerty, 2019, pp. 12-13)

Pakistan Takreek Insaaf (PTI) came into power after the general elections of 2018. After Pulwama Prime Minister Imran Khan address the Indian concerns over the terrorism of Pulwama. In his video message on National television PM IK asked India to share the evidences to Pakistan. It is examined that to get electoral support, the Pulwama attack gave an advantage to BJP for creating hate against Pakistan. Ruling BJP instead of carefully handling the incident, a huge campaign was launched to realize the people of India that Indian sovereignty is in deep danger. BJP used social media especially Facebook and WhatsApp to reshape the public sentiments in the favour of BJP in the coming elections. The Indian New Channels and print media also contributed by giving the advantage to the BJP government. Several talk shows were conducted in prime time to propagate the Pulwama attack and realizing the Indian people that Indian security is at high risk by the Pakistani side. After the Pulwama attack, the Modi government established extraordinarily use of electronic Media to publicize Pakistan as a terrorist state and the BJP regime as a defender of Indian security and deterrence. On the Indian claim that an airstrike on Balakot, destroy the training camps of terrorism. Pakistan reported that India has a strike in the forest area, there were no training camps in the targeted place (Wallace, 2020, pp. 38-39). 


\section{Conclusion}

Issues of security and terrorism in both countries have pushed the things difficult situation. The peace process remained stuck between both countries after terrorism. Security issues on both sides have created distrust in both states. Indian involvement in Pakistan's internal affairs and Pakistan-based Militant groups terrorism in India has made serious threats to the regional stability in South Asia. It is observed that the recent Kargil adventure after nuclear tests has worried the international world. The race of arms in the shape of missiles which can carry nuclear warheads for long-distance, endless efforts for increasing the military capabilities are the sign of insecurity and distrust on each other. Indian attempt to impose her hegemony in South Asia is not acceptable to Pakistan due to security threats from India. Kashmir, Siachen, Sir Creek, Water Dams project disputes and issues of security and terrorism have generated more complex situations in the region. Interference in internal matters of one another and blame gaming on each other for political advantage has also created gaps in the mutual relations. Both countries believed that internal interference is an attempt to weaken their sovereignty. Both sides blamed each other in this connection. After getting the status of nuclear powers, regional peace and security is a deep matter of concern for the peacebuilders. It is strongly considered that Indo-Pak nuclear capacities are a threat to one another and it is also a matter of great concern for the other regions of the world. Terrorism and security concerns are interconnected with each other and any act of terrorism in both countries always created distrust and a sense of insecurity.

Nuclear tests May 1998, Kargil war 1999, terrorist attacks on July 2001 in Kashmir parliament and attack on the Indian parliament in December 2001, blasts in Mumbai 2008 has reflected distrust and unrest which has made the ties more complex between two countries. Further Uri, Pathankot, and Pulwama attacks have made things worst and near to war. Pakistan banned the militant organizations' LeT and JeM which were involved in the terrorist activities in India. Pakistan has deep concerns about interfere of Indian authorities to destabilize her Balochistan province.

\section{Recommendations}

1. Steps should be taken by both sides to reduce the distrust and both sides should take measures against all kinds of terrorism.

2. Confidence-building measures should be adopted for creating a better environment for starting the dialogue process.

3. High-security measures should be taken by both sides to monitor the border areas and control on cross border terrorism.

4. The composite dialogs process should be re-started to address all disputed areas especially the Kashmir issue because it is considered the bone of contention between India and Pakistan.

5. Both countries should stop blame gaming on one another and should adopt the process of dialogues.

6. To check the border security, a sound mutual intelligence system must be developed for sharing information against non-stake actors who passed the border illegally.

7. Terrorism in all shapes should be condemned in principle, by both sides.

8. India and Pakistan should leave behind the blame gaming and political scoring and should treat terrorism and matter of security with complete interaction and cooperation. Both countries should develop a policy of zero tolerance to curb terrorism.

9. India, Pakistan leadership should not issue such provocative statements as make both nations aggressive and emotional against each other.

\section{References}

Adnan, M. (2013). Areas of Engagement and Security Threats between India and Pakistan. Journal of Political Studies, 20(1), 131-142.

Afzal, M. (2018). Pakistan under Siege: Extremism, Society and State. Washington D.C: Brooking Institution Press.

Ahmed, S., \& Das, S. (1998). Movements of the People, Ideas, Trade and Technology: Towards Peaceful Co-existence of India and Pakistan. Albuquerque NM: Sandia National Laboratories.

Amjad, A., Usman, A., \& Ajmad, U. (2017). Disrupting the Bilateral Relations between India and Pakistan. Journal of Politics and International Studies, 3(2), 15-18.

Budania, R. (2001). India National Security Dilemma: The Pakistan Factor and India's Policy Response. New Delhi: Indus Publishing Company. 
Chakma, B. (2015). South Asia's Nuclear Security. New York: Routledge.

Dutt, S., \& Bansal, A. (2013). South Asia Security: 21 Century Discourses. New York: Routledge.

Feyyaz, M. (2019, April). Contextualizing the Pulwama Attack in Kashmir: A Perspective from Pakistan. Perspectives on Terrorism, 13(2), 69-74.

Ganguly, S., \& Kapur, S. P. (2012). India Pakistan and Bomb: Debating Nuclear Stability in South Asia. New York: Columbia University Press.

Gupta, K. R., \& Shukla, V. (2009). Foreign Policy of India. New Delhi: Atlantic Publishers \& Distributors.

Haqerty, D. T. (2019). Nuclear Weapons and Deterrence Stability in South Asia. Gewerbestrasse: Springer.

Jabeen, M., Mazhar, M. S., \& Goraya, S. N. (2010). SAARC and Indo-Pak Relations. Journal of Political Studies, 127-145.

Khan, F. H. (2012). Eating Grass: The Making of Pakistani Bomb. Stanford: Stanford University Press.

Kumar, R. (2005). Making Peace with Partition. New Delhi: Penguin Books Pvt. Ltd.

Lovay, P. R. (2009). Asymmetric Warfare in South Asia: The Causes and Consequences of Kargil Conflict. Cambridge: Cambridge University Press.

Majeed, G. (2013). A History Analysis of India-Pakistan Relations. Journal of Political Studies, 212222.

Mujtaba, A. (2005). Sounding of South Asia. New Delhi: Sterling Publisher Pvt. Ltd.

Mustafa, G., \& Ashraf, M. T. (2016). Pak-India Head of States Sideline Meetings for Normalising of Conditions in both countries through SAARC Engine: Efforts and Outcomes. Orient Research Journal of Social Sciences, 63-76.

Paliwal, A. (2017). My Enemy's Enemy: India in Afghanistan from Soviet Invasion to the US Withdrawal. New York: Oxford University Press.

Perkovich, G. (2001). India's Nuclear Bomb: The Impact of Global Proliferation. Los Angeles: University of California Press.

Pernes, J., \& Moller, U. (2014). Coming together over Trade: A study of Resumed Dialogue between India and Pakistan. Asian Security, 221-240.

Prabhakar, W. P. (2003). Wars, Proxy wars and Terrorism: Post Independent India. New Delhi: Mittal Publications.

Pratap, R. (2018). Provisional Measures and the Yadhav Case. Groningen Journal of International Law, 5(2), 298-309.

Researchers, C. (2009). Issues of Terrorism and Homeland Security. London: SAGA.

Thorpe, E., \& Thorpe, S. (2020). General Studies. Chennai: Pearson Education India.

Trivedi, R. (2008). India Relations with her Neighbors. New Delhi: Gyan Publication House.

Wallace, P. (2020). India's 2019 Elections: The Hindutva Wave and Indian Nationalism. New Delhi: SAGA Publication.

Wignaraja, P., \& Hussian, A. (1989). The Challenge in South Asia: Development, Democracy and Regional Cooperation. New York: United Nations University Press.

Wirsing, R. G. (2003). Kashmir in the Shadow of War: Regional Rivalries in Nuclear Age. New York: M.E. Sharpe, Inc.

Wirsing, R. G. (2012). Baloch Nationalism and Geopolitics of Energy resources: The Changing Context of Separatism in Pakistan. Morrisville: Lulu.com. 